\title{
WEED FLORA IN ORGANIC COMMON MALLOW (Malva sylvestris L.)
}

\author{
Milka BRDAR-JOKANOVIĆ* , Branka LJEVNAIĆ-MAŠIĆ, Dejana DŽIGURSKI, \\ Anamarija KOREN, Larisa MERKULOV-POPADIĆ, Ljiljana NIKOLIĆ, Dušan ADAMOVIĆl
}

Summary: The aim of this study was to examine weed flora occurring in an organic common mallow (Malva sylvestris L.), a newly established crop at the experimental field Bački Petrovac, Institute of Field and Vegetable Crops, Novi Sad, during the growing season of 2014. The weed flora consisted of six species, with even a half being invasive for Vojvodina region (Sorghum halepense, Amaranthus retroflexus, Datura stramonium). The observed low floristic diversity may be related to unbalanced ecological conditions in a newly established crop, invasive species, comparatively low fertilization, allelopathic relations, and possibly robust habitus of the main crop. However, although the flora was low in diversity, both narrow and broadleaf species were represented, with the average infestation as high as 16 individuals per $\mathrm{m}^{2}$. In addition, since the recorded weeds flower from Mart to November, until the development of more efficient methods that are in compliance with the principles of organic agriculture, mechanical weeding should be performed at least three times during the growing season. To our knowledge, this is the first such report on organic common mallow in agro ecological conditions of Serbian province Vojvodina and represents the first step in establishing the adequate weed control measures.

Key words: Malva sylvestris, organic production, weed flora.

\section{INTRODUCTION}

Due to variety of uses as both edible and plant with possible therapeutic properties, common mallow (Malva sylvestris L.) occupies an important place among medicinal and aromatic plants and spices. The effects of numerous biologically active compounds detected in all parts of the mallow plant (flavonoids, mucilages, terpenoids, phenols, enzymes etc.) are the subject of studies on its antimicrobial, anti-inflammatory, analgesic, antioxidant and other properties. Although native to Europe, Asia and North Africa, the species is naturalized all over the world. Despite of the potential for using the mallow in medicinal, veterinary, industrial and culinary purposes, the largest part of the exploited plant material still comes from natural resources. Cultivating would be of great benefit for several reasons among which is probably the most important quality control, since the plant accumulates certain pollutants and has even been proposed as bio indicator of pollution levels in the environment. These facts point to the organic production as the system of choice for cultivation of common mallow. However, introducing the already rarely grown plant species in the organic production comes with certain difficulties, such as establishing optimal plant spacing, nutrient and water demands and timing of agro technical procedures. Moreover, since herbicides are not allowed in Serbian herb production, weed control is emerging as one of the most serious difficulties for both organic and conventional production (Gasparetto et al., 2012; Carrubba and Militello, 2013; Matković et al., 2014; Barosso et al., 2015; Jaradat et al., 2015; Terzi et al., 2016; Delfine et al., 2017).

This study was conducted in order to examine weed flora occurring in a newly established crop of organic common mallow. To our knowledge, this is the first such report for organic common mallow in agro ecological conditions of Serbian province Vojvodina and represents the first step in establishing the adequate weed control measures.

\footnotetext{
${ }^{1}$ Milka Brdar-Jokanović, PhD, Senior Research Associate, Anamarija Koren, PhD, Research Associate, Larisa MerkulovPopadić, Agric. Eng., Technical Associate, Dušan Adamović, PhD, Principal Research Fellow, Institute of Field and Vegetable Crops, Maksima Gorkog 30, 21000 Novi Sad, Serbia; Branka Ljevnaić-Mašić, PhD, Associate Professor, Dejana Džigurski, PhD, Full Professor, Ljiljana Nikolić, PhD, Full Professor, University of Novi Sad, Faculty of Agriculture, Trg Dositeja Obradovića 8, 21000 Novi Sad, Serbia.

*Corresponding author: Milka Brdar-Jokanović, e-mail: milka.brdar@ifvens.ns.ac.rs, phone: +381 21780365.

*This article results from the projects TR 31027, 31013 and 31059 (2011-2018), supported by Ministry of Education, Science and Technological Development of Republic of Serbia.
} 


\section{MATERIAL AND METHODS}

This study was conducted at the organic experimental field Bački Petrovac, Alternative Crops and Organic Production Department, Institute of Field and Vegetable Crops, Novi Sad, Serbia. The main crop was common mallow (Malva sylvestris L.), newly established and intended for seed production in growing season of 2014. The mallow was sown in the late April in 12 rows, each $80 \mathrm{~m}$ long, with between-row spacing of $70 \mathrm{~cm}$. Besides farmyard manure fertilization in November 2011 at the rate of $15 \mathrm{t} \mathrm{ha}^{-1}$ and the usual pre-sowing land cultivation, other agro technical practices were not performed.

Weeds were studied at the full common mallow vegetative expansion, at the beginning of June. The infestation (number of weed individuals per $\mathrm{m}^{2}$ ) was recalculated from $9 \mathrm{~m}^{2}$ randomly chosen crop sections, replicated five times. The noted species were identified according to Josifović (1970-1977). Ecological indices for the species for both Malva sylvestris and the weeds are given according to Landolt (2010), except for flowering months (Čanak et al., 1978), since the flowering of the plant species may be dependent on ecological conditions in the particular geographic area. The invasiveness of the noted weeds in Vojvodina region (IASV, 2011), Europe (DAISIE database) and world (ISSG, 2015) was added to the description.

\section{RESULTS AND DISCUSSION}

In spite of the high average infestation of 16 individuals per $\mathrm{m}^{2}$ of the crop surface and the presence of both narrow and broadleaf species, weed flora occurring in organic common mallow (Malva sylvestris L.) consisted of six taxa only (Table 1,2). Amaranthus retroflexus and Sorghum halepense, both noxious weeds with an increasing abundance, dominated with five individuals per $\mathrm{m}^{2}$ each. Sorghum halepense is considered as a serious pest in the world (Rout and Chrzanowski, 2009; Acciaresi and Guiamet, 2010; Iamonico, 2010); it is a neophyte introduced as a forage crop from North Africa and Southwest Asia afterwards easily spread globally. In addition to the two, as invasive for Vojvodina was identified Datura stramonium, very poisonous but also a plant of potential medicinal value, which infested the mallow crop with three plants per $\mathrm{m}^{2}$. Therefore, a half of the recorded species is invasive in the region and should be monitored. A. retroflexus and D. stramonium original distribution area is North America and they are therefore considered as neophytes. Although not in Vojvodina, the recorded Senecio vulgaris is invasive in both Europe and the world. It is the archaeophyte in the region, together with less frequently represented (one individual per $\mathrm{m}^{2}$ ) Convolvulus arvensis and Polygonum convolvulus.

Table 1. Weed flora in organic common mallow (Malva sylvestris L.)

\begin{tabular}{|c|c|c|c|c|c|}
\hline Weed species & Class & $\begin{array}{c}\text { Infestation } \\
\text { (individuals per } \mathrm{m}^{2} \text { ) }\end{array}$ & Vojvodina & $\begin{array}{c}\text { Invasiveness in } \\
\text { Europe }\end{array}$ & world \\
\hline Amaranthus retroflexus $\mathrm{L}$. & Dicotyledons & 5.0 & + & - & - \\
\hline Convolvulus arvensis $\mathrm{L}$. & Dicotyledons & 1.0 & - & - & - \\
\hline Datura stramonium L. & Dicotyledons & 3.0 & + & - & - \\
\hline Polygonum convolvulus L. & Dicotyledons & 1.0 & - & - & - \\
\hline Senecio vulgaris L. & Dicotyledons & 1.0 & - & + & + \\
\hline Sorghum halepense (L.) Pers. & Monocotyledons & 5.0 & + & - & + \\
\hline
\end{tabular}

In order to further investigate the observed weed flora in terms of the life strategies and history, distribution patterns, main properties of the habitat occupying etc., a detailed analysis of ecological indices was performed (Table 2). Belonging to flora spontaneously occurring and presumably indigenous in Vojvodina region, Malva sylvestris was also included in the analysis.

As expected for plants from agricultural environments, all the species are weeds and ruderals, occupying primarily eutrophic terrestrial habitats, both natural and anthropogenic. Apart from urbanoneutral main crop, the recorded weeds are moderately to strictly urbanophilous. They are adapted to suboceanic and subcontinental climate and grow from lower mountains to very warm collines, on well-lit places. They indicate weakly acid to alkaline soil, fertile with moderate humus content, moderately dry to moderately moist, with little to moderately varying in moisture, bad to moderately aerated. Out of seven considered plant species, two are confirmed as salinity tolerant, and there is no information for the remaining five, implying the elevated salt content in the soil. Heavy metal tolerance was confirmed for five and unknown for two plant species found in the organic field, which may be explained with close proximity of the fairly frequent traffic. The weed species are therophytes or geophytes, which are the most common life forms for agricultural environments (José-María et al., 2011); due to the regularly performed various weed control measures. Competitive, stress tolerant and ruderal life strategies are present, with 
variety of dissemination and fertilization types, as well as the possible pollinators. The majority is with seed longevity from 20 to 100 years.

Comparing to other organic crops from the Vojvodina region, the observed flora may be considered as commonly occurring, since all six weeds were found in the previously surveyed lettuce, pepper, potato, basil and dill. The noted species, except Senecio vulgaris, were also reported for organic rocket salad and onion (Džigurski et al., 2011; 2013; 2015; Nikolić et al., 2011; 2013; Ljevnaić-Mašić et al., 2015a; 2015b). However, the flora from other surveys was much more diverse, being in the range from 23 to 31 species in vegetables, nine in dill and 18 in basil crops.

Table 2. Ecological and biological characteristics (Landolt, 2010) for weed flora in organic common mallow (Malva sylvestris L.)

\begin{tabular}{|c|c|c|c|c|c|c|c|}
\hline Plant species & $\begin{array}{l}\text { Malva } \\
\text { sylvestris }\end{array}$ & $\begin{array}{l}\text { Amaranthus } \\
\text { retroflexus }\end{array}$ & $\begin{array}{l}\text { Convolvulus } \\
\text { arvensis }\end{array}$ & $\begin{array}{l}\text { Datura } \\
\text { stramonium }\end{array}$ & $\begin{array}{l}\text { Polygonum } \\
\text { convolvulus }\end{array}$ & $\begin{array}{l}\text { Senecio } \\
\text { vulgaris }\end{array}$ & $\begin{array}{l}\text { Sorghum } \\
\text { halepense }\end{array}$ \\
\hline \multicolumn{8}{|l|}{ Climate indicators } \\
\hline Temperature $\mathrm{T}$ & 4 & 4 & 4 & 5 & 3.5 & 3.5 & 5 \\
\hline Continentality $\mathrm{K}$ & 4 & 3 & 4 & 2 & 3 & 3 & 2 \\
\hline Light L & 4 & 4 & 4 & 4 & 4 & 4 & 4 \\
\hline \multicolumn{8}{|l|}{ Soil indicators } \\
\hline Humidity $\mathrm{F}$ & 2.5 & 2.5 & 2.5 & 3 & 2.5 & 3 & 2 \\
\hline Humidity variation $\mathrm{W}$ & 2 & 2 & 2 & 1 & 1 & 1 & 2 \\
\hline Chemical reaction $\mathrm{R}$ & 4 & 3 & 4 & 3 & 3 & 4 & 4 \\
\hline Nutrient content $\mathrm{N}$ & 4 & 4 & 4 & 4 & 4 & 4 & 4 \\
\hline Salinity tolerance $S$ & - & $\mathrm{s}$ & - & $\mathrm{s}$ & - & - & - \\
\hline Heavy metal tolerance $\mathrm{M}$ & $\mathrm{m}$ & $\mathrm{m}$ & $\mathrm{m}$ & - & $\mathrm{m}$ & $\mathrm{m}$ & - \\
\hline Humus content $\mathrm{H}$ & 3 & 3 & 3 & 3 & 3 & 3 & 3 \\
\hline Dispersion D & 3 & 1 & 1 & 3 & 3 & 3 & 3 \\
\hline \multicolumn{8}{|l|}{ Growth and life strategies } \\
\hline Life form LF & $\mathrm{k}-\mathrm{t}$ & $\mathrm{t}$ & g.li & $\mathrm{t}$ & t.li & $\mathrm{t}$ & $\mathrm{g}$ \\
\hline Leaf duration BD & $\mathrm{w}$ & $\mathrm{s}$ & $\mathrm{s}$ & $\mathrm{s}$ & $\mathrm{s}$ & w s & $\mathrm{s}$ \\
\hline Root depth WT & 4 & 3.5 & 4.5 & 2.5 & 3 & 1.5 & 3 \\
\hline Reserve organs RO & Wv & - & Rs & Wd & Wv & - & $\mathrm{Rh}$ \\
\hline Life strategy KS & crs & crr & $\mathrm{crr}$ & crr & crr & $\mathrm{rrr}$ & $\mathrm{ccc}$ \\
\hline \multicolumn{8}{|l|}{ Life history } \\
\hline Dissemination DA & Bo At & Ep En & Dy & Me At & En Dy & $\mathrm{Me}$ & Bo Dy \\
\hline Vegetative prop. VA & $\mathrm{Kv}$ & $\mathrm{Kv}$ & Ws & $\mathrm{Kv}$ & $\mathrm{Kv}$ & $\mathrm{Kv}$ & $\mathrm{Au}$ \\
\hline Fertilization FS & $\mathrm{zW}$ & mo & $\mathrm{zW}$ & $\mathrm{zW}$ & $\mathrm{zW}$ & ve & $\mathrm{zW}$ \\
\hline Max age MA & - & $\mathrm{d}$ & p3 & $\mathrm{p} 1$ & $\mathrm{p} 1$ & p1 & - \\
\hline $\begin{array}{l}\text { Time of flowering }{ }^{* *} \\
\text { BZ }\end{array}$ & V-IX & VI-IX & VI-IX & VI-IX & VI-IX & III-XI & VI-VII \\
\hline Pollinators BS & $\begin{array}{l}\text { my me }(v e) \\
(\mathrm{ps})(\mathrm{ca}) w a ?\end{array}$ & an (my) (ca) & au my me ps & au ca & $\mathrm{au}$ & $\begin{array}{l}\text { au (my) } \\
(\mathrm{me})(\mathrm{le})\end{array}$ & an? \\
\hline Cut tolerance MV & 2 & - & 2 & - & - & - & - \\
\hline Seed longevity SU & 5 & 4 & 4 & 4 & 4 & 2 & 3 \\
\hline In situ dominance DG & 2 & 3 & 3 & 1 & 2 & 3 & 3 \\
\hline Poison, med., edible GI & $\mathrm{he}$ & $\mathrm{e}$ & $\operatorname{tg} h$ & $\operatorname{gg~h}$ & $\mathrm{e}$ & gg h & $\mathrm{e}$ \\
\hline \multicolumn{8}{|c|}{ Distribution in space and time } \\
\hline Geographic GV & B6 & $\mathrm{A} 2$ & B6a & $\mathrm{A} 2 \mathrm{a}$ & C1 & $\mathrm{C} 2 \mathrm{~b}$ & $\mathrm{~A} 4 \mathrm{a}$ \\
\hline Habitat LR & $2.1,2$ & $2.1,2,5,7$ & $2.1,2,56.2$ & $2.1,2,93.3$ & $2.1,2,5,7$ & $2.1,2,5,6$ & $2.1,2,9$ \\
\hline Ecologic groups EG & 7 & 7 & 7 & 7 & 7 & 7 & 7 \\
\hline Immigration $\mathrm{AE}$ & $\mathrm{I} / \mathrm{A}$ & $\mathrm{N}$ & A & $\mathrm{N}$ & A & A & $\mathrm{Jn}$ \\
\hline Human impact EM & 3 & 5 & 4 & 5 & 4 & 4 & 4 \\
\hline Abundance tendency VE & - & $<$ & $<$ & $=$ & $=$ & $=$ & $<$ \\
\hline
\end{tabular}

${ }^{*}$ Čanak et al. (1978)

T: 3.5 lower montane and upper colline, 4 colline, 5 very warm colline; K: 2 suboceanic, 3 suboceanic and subcontinental, 3 subcontinental; L: 4 well lit places; F: 2 moderately dry, 2.5 fresh, 3 moderately moist; W: 1 moisture little varying, 2 moisture 
moderately varying; R: 3 weakly acid to weakly neutral, 4 neutral or alkaline; N: 4 fertile; S: - no information, s salt tolerant; M: no information, m heavy metal tolerant; H: 3 moderate; D: 1 bad aeration - compacted or wet soil, 3 moderate aeration; LF: $g$ geophytes, g.li geophytes trailing, $\mathrm{t}$ therophytes, t.li therophytes trailing, k-t ephemeral hemicryptophytes-therophytes; BD: $\mathrm{s}$ deciduous, w wintergreen; WT: $1.580 \%$ of roots above $25 \mathrm{~cm}, 2.580 \%$ of roots at $25-50 \mathrm{~cm}, 3$ roots at $50-100 \mathrm{~cm}, 3.590 \%$ of roots at $50-100 \mathrm{~cm}, 4$ roots at 100-200 cm, $4.595 \%$ of roots 100-200 cm; RO: - no special organs to store energy, Rh thick rhizome, Rs inconspicuous reserve organ, Wd many thick non-lignified roots, Wv root swelling; KS: ccc competitive, crr competitive ruderals, crs competitive ruderal stress tolerant, rrr ruderal; DA: At anthrochory, Bo bolechory, Dy dysochory, En endochory, Ep epichory, Me meterochory; VA: Au below-ground runners, Kv no vegetative dispersal parts, Ws root shoots; FS: mo unisexual and monoecious, ve polysexual, zw hermaphroditic and normal sexual; MA: d growth rings indistinct or lacking, $\mathrm{p}$ root collar; BS: an anemogamous, au autogamous, ca cantharophilous, le lepidopterophilous, me melittophilous, my myophilous, ps psychophilous, ve vespidophilous, wa by heteroptera, ( ) inferior importance, ? doubtful information; MV: - hardly grows in grassland; does not tolerate annual cut or grazing, 2 little; SU: 2 1-5 years, 3 5-20, 4 20-100, 5 more than 100; DG: 1 scattered, 2 scattered or in small groups, 3 in larger groups; GI: e edible, gg very poisonous, h medical, tg poisonous for individual animal species; GV: A2 North America, spread across most of the continent, A2a North America, mostly southern states and Mexico, A4a Southwest Asia, rarely in southeast Europe; B6 Europe, West and Central Asia, rarely North Africa, B6a Europe, West and Central Asia, south, mostly warm temperate deciduous forests or warm steppes, C1 Mediterranean in broader sense, C2b Mediterranean, east; LR: 2 eutrophic terrestrial vegetation, natural or anthropogenic, 2.1 fields and cultivated areas, 2.2 ruderal and half-ruderal, 2.5 river banks, alluvium, gravel, 2.6 clearings, forest roads, burned places, 2.7 parks, lawns, gardens, 2.9 agricultural plants, 3.3 sandbanks in the broader sense, 6.2 dry and semi-dry grasslands, meadows and pastures; EG: 7 weeds and ruderal plants; AE: A archaeophytes, I/A presumably indigenous in some areas of the study region, Jn young species - neophytes, $\mathrm{N}$ neophytes; EM: 3 indifferent - urbanoneutral, 4 moderately hemerobic - moderately urbanophilous, 5 hemerobic - strictly urbanophilous; VE: = abundance unchanged - apart from local presence, $<$ abundance increasing.

There are several factors that may have contributed to the pronounced differences in weed flora diversity among the observed vegetables, medicinal plants and spices. Agro ecological conditions in the recently founded organic field and newly established common mallow crop in it are certainly still not balanced, with invasive weed species accounting a half of the recorded taxa. In addition, despite of the long-term beneficial effects of farmyard manure on soil properties (Eghball et al., 2004), the organic mallow is still comparatively low fertilized. In addition, allelopathic relations among the weeds which are all edible, poisonous or medicinal (Butnariu, 2012; Golubinova and Ilieva, 2014) and the medicinal and edible main crop (Jalali et al., 2013) may be also considered. Although the basil, dill and common mallow weed floras were low in diversity when compared to those from the vegetable crops (11 and 26.4 on average, respectively), further research is required to confirm the hypothesis on the suppressing effects of aromatic and medicinal plants and spices on weeds. Finally, the Malva sylvestris robust habitus itself may contribute to the observed low weed flora diversity. Twice the smaller number of weed taxa found in the dill crop characterized by vigorous, high and branched plants (Ljevnaić-Mašić et al., 2015b), with respect to weeds from the crop of delicate basil plants (Džigurski et al. 2015) supports this viewpoint.

In addition, since the recorded weeds flower from Mart to November, until the development of more efficient methods that are in compliance with the principles of organic agriculture, mechanical weeding should be performed at least three times during the growing season. To our knowledge, this is the first such report on organic common mallow in agro ecological conditions of Serbian province Vojvodina and represents the first step in establishing the adequate weed control measures.

\section{CONCLUSION}

The weed flora occurring in organic common mallow (Malva sylvestris L.) consisted of six species only, with a half being invasive in Vojvodina region (Amaranthus retroflexus, Sorghum halepense and Datura stramonium). Both narrow and broadleaf species were represented and average infestation was 16 individuals per $\mathrm{m}^{2}$. The low floristic diversity may be explained by unbalanced ecological conditions in the recently founded organic production system and newly established crop in it, presence of invasive species, comparatively low fertilization, allelopathic relations, and possibly robust habitus of the main crop. The recorded species flower from Mart to November, therefore weeding in compliance with organic agriculture should be performed at least three times throughout the mallow growing season.

\section{REFERENCES}

ACCIARESI, H.A., GUIAMET, J.J.: Below- and above-ground growth and biomass allocation in maize and Sorghum halepense in response to soil water competition. Weed Res., 50(5): 481-492, 2010.

BAROSSO, J., MILLER, Z.J., LEHNHOFF, E.A., HATFIELD, P.G., MENALLED, F.D.: Impacts of cropping system and management practices on the assembly of weed communities. Weed. Res., 55(4): 426-435, 2015. 
BUTNARIU, M.: An analysis of Sorghum halepense's behavior in presence of tropane alkaloids from Datura stramonium extracts. Chem. Cent. J., 6:75, 2012.

CARUBBA, A., MILITELlO, M.: Nonchemical weeding of medicinal and aromatic plants. Agron. Sustain. Dev., 33:551-561, 2013.

ČANAK, M., PARABUĆSKI, S., KOJIĆ, M.: Ilustrovana korovska flora Jugoslavije. Matica srpska. Novi Sad, Srbija, 1978.

DAISIE: European Invasive Alien Species Gateway (http://www.europe-aliens.org)

DELFINE, S., MARRELli, M., CONFORTI, F., FORMISANO, C., RIGANO, D., MENICHINI, F., SENATORE, F.: Variation of Malva sylvestris essential oil yield, chemical composition and biological activity in response to different environments across Southern Italy. Ind. Crops Prod., 98:29-37, 2017.

DŽIGURSKI, D., KNEŽEVIĆ, A., LJEVNAIĆ-MAŠIĆ, B.: Ecological and plant-geographic analysis of the weed flora in organic production of rocket salad -Eruca vesicaria (L.) Cav. (syn. Eruca sativa Miller) (Brassicaceae Burn., Capparidales). Journal on Processing and Energy in Agriculture, 15(1): 42-45, 2011.

DŽIGURSKI, D., NIKOLIĆ, LJ., LJEVNAIĆ-MAŠIĆ, B.: Weed flora in organic onion production - Allium cepa L. (Alliaceae Borkhausen Amaryllidales). Journal on Processing and Energy in Agriculture, 17(3): 130-133, 2013.

DŽIGURSKI, D., LJEVNAIĆ-MAŠIĆ, B., NIKOLIĆ, LJ., BRDAR-JOKANOVIĆ, M., ADAMOVIĆ, D.: Weed flora in basil (Ocimum basilicum L., Lamiaceae Martynov 1820, Lamiales) grown in conventional and organic production. Contemporary Agriculture, 64(1-2): 14-19, 2015.

EGHBALL, B., GINTING, D., GILLEY, J.E.: Residual effects of manure and compost applications on corn production and soil propertis. Agron. J., 96:442-447, 2004.

GASPARETTO, J.C., MARTINS, C.A.F., HAYASHI, S.S., OTUKY, M.F., PONTAROLO, R.: Ethnobotanical and scientific aspects of Malva sylvestris L.: a millennial herbal medicine. J. Pharm. Pharmacol., 64(2): 172-189, 2012.

GOLUBINOVA, I., ILIEVA, A.: Allelopathic effects of water extracts of Sorghum halepense (L.) Pers., Convolvulus arvensis L. and Cirsium arvense Scop. on early seedling growth of some leguminous crops. Pestic. Phytomed. (Belgrade), 29(1):35-43, 2014. IAMONICO, D.: Biology, life-strategy and invasiveness of Amaranthus retroflexus L. (Amaranthaceae) in central Italy: preliminary remarks. Botanica Serbica, 34(2): 137-145, 2010.

IASV: Lista invazivnih vrsta na području AP Vojvodine = List of invasive species in AP Vojvodina [Internet]. Version 0.1 beta. Anačkov G, Bjelić-Čabrilo O, Karaman I, Karaman M, Radenković S, Radulović S, Vukov D \& Boža P, eds. Novi Sad (Serbia): Departman za biologiju i ekologiju; 2011 [cited February 25], http://iasv.dbe.pmf.uns.ac.rs/ Serbian, English, 2011.

INVASIVE SPECIES SPECIALIST GROUP ISSG 2015. The Global Invasive Species Database. Version 2015.1 <http://www.iucngisd.org/gisd/> Downloaded on March 092017

JALALI, M., GHEYSARI, H., AZIZI, M., ZAHEDI, S.M., MOOSAVI, S.A.: Allelopathic potential of common mallow (Malva sylvestris) on the germination and the initial growth of blanket flower, plumed cockscomb and sweet William. Int. J. Agric. Crop Sci., 5(15): 1638-1641, 2013.

JARADAT, N.A., ABUALHASAN, M., ALI, I.: Comparison of anti-oxidant activities and exhaustive extraction yields between wild and cultivated Cyclamen persicum, Malva sylvestris and Urtica pilulifera leaves. J. Appl. Pharm. Sci., 5(4):101-106, 2015.

JOSÉ-MARÍA, L., BLANCO-MORENO, J.M., ARMENGOT, L., SANS, F.X.: How does agricultural intensification modulate changes in plant community composition? Agric., Ecosyst. Environ., 145(1): 77-84, 2011.

JOSIFOVIĆ, M.: Flora SR Srbije, I-IX (M. Josifović, ed.). SANU, Beograd, Srbija, 1970-1977.

LANDOLT, E.: Flora indicative - Ecological indicator values and biological attributes of the flora of Switzerland and the Alps (E. Landolt, ed.). Haupt Verlag, Bern, Swiss, 2010.

LJEVNAIĆ-MAŠIĆ, B., NIKOLIĆ, LJ., DŽIGURSKI, D.: Weeds in organic production of pepper (Capsicum annuum L.) bioindicators of habitat conditions. Journal on Processing and Energy in Agriculture, 19(5): 266-272, $2015 \mathrm{a}$.

LJEVNAIĆ-MAŠIĆ, B., DŽIGURSKI, D., NIKOLIĆ, LJ., BRDAR-JOKANOVIĆ, M., ADAMOVIĆ, D.: Weed flora in dill (Anethum graveolens L., Apiaceae, Apiales) grown in conventional and organic production systems. Ratar. Povrt., 52(1): 14-17, $2015 \mathrm{~b}$.

MATKOVIĆ, A., VRBNIČANIN, S., MARKOVIĆ, T., BOŽIĆ, D.: Metode primenjive za proučavanje korova u lekovitom bilju. Lek. sirov., 34:29-43, 2014.

NIKOLICH, L., DZIGURSKI, D., LJEVNAICH-MASICH, B., CABILOVSKI, R., MANOJLOVICH M.: Weeds of lattuce (Lactuca sativa L. subsp. secalina) in organic agriculture. Bulg. J. Agric. Sci., 17(6): 736-743, 2011.

NIKOLIĆ, LJ., ILIĆ, O., DŽIGURSKI, D., LJEVNAIĆ-MAŠIĆ, B.: Analysis of weed flora in conventional and organic potato production. Biologica Nyssana, 4(1-2): 9-14, 2013.

ROUT, M.E., CHRZANOWSKI, T.H.: The invasive Sorghum halepense harbors endophytic N2-fixing bacteria and alters soil biogeochemistry. Plant Soil, 315(1): 163-172, 2009.

TERZI, M., ACEMI, A., ERGÜL, H.A., ÖZEN, F.: PAH and PCB Levels in Malva sylvestris L. specimens collected from Kocaeli, Turkey. Biomonitoring, 2:42-46, 2016. 


\title{
KOROVSKA FLORA U ORGANSKOM CRNOM SLEZU (Malva sylvestris L.)
}

\author{
Milka BRDAR-JOKANOVIĆ, Branka LJEVNAIĆ-MAŠIĆ, Dejana DŽIGURSKI, Anamarija STOJANOVIĆ, \\ Larisa MERKULOV-POPADIĆ, Ljiljana NIKOLIĆ, Dušan ADAMOVIĆ
}

Rezime: Cilj ovog rada je bio da se ispita korovska flora u organskom crnom slezu (Malva sylvestris L.), novozasnovanom usevu na eksperimentalnoj parceli Bački Petrovac, Institut za ratarstvo i povrtarstvo, Novi Sad, tokom sezone 2014. Zabeleženo je šest korovskih vrsta, od kojih je pola invazivno za područje Vojvodine (Sorghum halepense, Amaranthus retroflexus, Datura stramonium). Mali floristički diverzitet bi mogao biti vezan sa nebalansiranim ekološkim uslovima u novom usevu, prisustvom invazivnih korovskih vrsta i srazmerno slabijom prihranom. Postoji mogućnost da su određeni uticaj ispoljili i robusni habitus crnog sleza i alelopatski odnosi. Međutim, iako diverzitet nije veliki, zastupljeni su i uskolisni i širokolisni korovi, sa visokom srednjom zakorovljenošću od 16 individua po $\mathrm{m}^{2}$. Pošto ovi korovi cvetaju od marta do novembra, do razvoja novih metoda $\mathrm{u}$ skladu sa principima organske proizvodnje, mehaničko uklanjanje treba obaviti najmanje tri puta tokom sezone. Prema našim saznanjima, ovo je prvi izveštaj o organskom crnom slezu u agroekološkim uslovima Vojvodine i predstavlja prvi korak ka uspostavljanju odgovarajućih mera za kontrolu korova

Ključne reči: Malva sylvestris, organska proizvodnja, korovska flora.

Received / Primljen: 02.04.2018. Accepted / Prihvaćen: 21.05.2018. 